\title{
HUBUNGAN ANTARA DERAJAT OBSTRUKSI SERANGAN AKUT ASMA DENGAN KADAR IgE, IFN- $\gamma$ DAN IL-4 TOTAL SERUM
}

\author{
HMS. Chandra Kusuma *, Kusworini Handono Kalim ${ }^{* *}$,Wibi Riawan ${ }^{* * *}$, Masdar Muid ${ }^{* * * *}$ \\ "Bagian IImu Kesehatan Anak RSUD Dr. Saiful Anwar/ Fakultas Kedokteran Unibraw \\ ${ }^{*}$ Bagian Patologi Klinik RSUD Dr. Saiful Anwar/ Fakultas Kedokteran Unibraw \\ *** Laboratorium Biomedik Fakultas Kedokteran Unibraw \\ **** Bagian IImu Kesehatan Anak, Divisi Neurologi RSUD Dr. Saiful Anwar/ Fakultas Kedokteran Unibraw
}

\begin{abstract}
Acute bronchial asthma is a common medical emergency the world over. There now exists compelling evidence of a role for $T_{2}-T_{1}$ paradigm in the pathogenesis of asthma in children. We hypothesized that childhood asthma is associated with the activation of Th2$T h_{1}$ lymphocytes whose products regulate at least in part, the expression of IgE, IFN- $\gamma$ and IL-4 and thereby disease severity. Our aims, therefore were to compare the level of total IgE, total IL-4 and total IFN- $\gamma$ in serum from asthmatic and non asthmatic control children matched for age and sex, and to attempt to correlate the IgE, IL-4, and IFN- $\gamma$ total level of serum in the asthmatics children with disease severity. Fifty one children with acute asthma exacerbation were compare with thirty one no asthmatics normal children matched for age and sex. The level of IgE, IL-4, and IFN- $\gamma$ were measured using Elisa. Asthma severity was assessed by a symptom score and spirometri. The level of IgE and II-4 in the serum of the asthma were elevated as compared to the non asthmatic normal controls, whereas the IFN- $\gamma$ was decreased. There was a significant correlation between elevated levels of IgE and IL-4 with the acute asthma exacerbation severity, whereas the decreased level of IFN- $\gamma$ was not. Conclusions. The increased levels of IgE, IL-4 and the ratio of IL-4/IFN- $\gamma$ play a crucial role in the acute asthma exacerbation severity.
\end{abstract}

\section{PENDAHULUAN}

Proses inflamasi saluran nafas mempunyai peran utama dalam patogenesis manifestasi klinis asma. Proses inflamasi ini ditandai oleh gambaran yang karakteristik yaitu adanya destruksi sel epitel, hipertropi otot polos, penebalan membran basal dan infiltrasi oleh sel-sel radang terutama sel eosinofil, sel mast, dan sel limfosit $T$ (1). Selama proses inflamasi bermacam mediator dilepas dan menimbulkan kerusakan jaringan. Sitokin sel $\mathrm{Th}_{2}$ seperti IL-4, IL-13, dan IL-15 mendominasi temuan yang ada pada hasil biopsy dan pemeriksaan sekret dari bronkoalveolar penderita asma $(1,2,3)$. Dibuktikan pula bahwa terjadinya asma pada anak-anak oleh karena timbulnya gangguan keseimbangan antara sel $T h_{1}$ dan $T h_{2}$ dengan terjadinya pergeseran kearah sel $\mathrm{Th}_{2}$. Pergeseran pelepasan sitokin dari kedua tipe sel Th tersebut menentukan terjadinya proses inflamasi dan timbulnya asma $(2,3,4)$.

Walaupun demikian masih belum banyak diteliti adanya hubungan antara kadar sitokin dengan beratnya derajat obstruksi yang terjadi didalam saluran nafas penderita asma yang sedang mengalami serangan. Ada beberapa penelitian hasil otopsi dari penderita yang meninggal karena status asma menunjukkan adanya proses inflamasi yang konsisten dengan paradigma sel $\mathrm{Th}_{2}$ dan ditemukannya sel eosinofil dan sel limfosit dalam jumlah besar (3).

Tujuan penelitian ini untuk mencari hubungan antara derajat obstruksi serangan akut asma dengan kadar IgE dan sitokin serum penderita asma.

Jurnal Kedokteran Brawijaya, Vol. XX, No.2, Agustus 2004.

Korespondensi: HMS. Chandra Kusuma; Lab. IKA FK Unibraw; Jl. Veteran Malang-65145; telp (0341) 580991, 567192 fax (0341)564755

\section{METODE}

Semua penderita asma yang mengalami serangan dan masuk rumah sakit mulai 1 Januari 2002 s/d Desember 2003 di ruang anak RSUD Dr. Saiful Anwar, RS Lavalette dan RSI Aisyah di Malang diikutkan dalam penelitian ini. Sebagai kontrol adalah 31 anak sehat.

Diagnosis asma dibuat atas dasar adanya serangan mengi berulang dan pemeriksaan spirometri menunjukkan reversibilitas $\geq 15 \%$ atau FEV1 (Forced Expiratory Volume in 1 second) $\leq 90 \%$. Derajat serangan asma ditentukan oleh nilai FEV 1 :

- Ringan : FEV $1 \geq 80 \%$

- Sedang : FEV $1 \geq 60 \% \leq 80 \%$

- Berat : FEV $1 \leq 60 \%$

Semua orang tua penderita yang ikut dalam penelitian menandatangani surat persetujuan (Informed Consent) dan penelitian sudah disetujui komite etik rumah sakit.

Penelitian ini merupakan studi cross-sectional. Pada hari pertama masuk rumah sakit segera di ukur faal paru, pengambilan darah melalui vena untuk menghitung kadar lgE, IL4 dan IFN- $\gamma$ total dalam serum dengan menggunakan tehnik ELISA. Pengukuran faal paru dengan menggunakan Spirometer Auto Spiror discom 21.

Nilai terbaik dari tiga kali pengukuran digunakan dalam penelitian yang tergambar sebagai persentasi nilai prediksi dan ditentukan segera setelah penderita masuk rumah sakit. Reversibilitas diukur setelah penderita mendapatkan $1-3$ kali inhalasi solbutamol. Analisis data statistik menggunakan program SPSS versi 10.0 .

\section{HASIL PENELITIAN}

Telah berhasil dikumpulkan 51 kasus asma dan 31 orang anak sehat sebagai kontrol. Distribusi jenis kelamin anak asma adalah 40 laki-laki dan 11 orang perempuan dengan rasio 3,6. Kontrol anak sehat 15 laki-laki dan 16 perempuan. 
Tabel 1. Hasil analisis deskriptif

\begin{tabular}{lrrrr}
\hline \multirow{2}{*}{ Variabel } & \multicolumn{2}{c}{ Asma(+) bronkiolitis RSV } & \multicolumn{2}{c}{ Anak sehat } \\
\cline { 2 - 5 } & \multicolumn{1}{c}{ Mean } & SD & \multicolumn{1}{c}{ Mean } & SD \\
\hline Umur (tahun) & 8.1 & 1.7 & 7.9 & 1.2 \\
FEV1 (\%) & 61.32 & 8.19 & 97.71 & 6.24 \\
IgE (Unit) & 1050.029 & 560.241 & 112.929 & 67.057 \\
IL-4 (pg/ml) & 46.82127 & 26.47280 & 10.31414 & 2.09183 \\
IFN- $\gamma$ (pg/ml) & 12.91580 & 6.57795 & 13.76671 & 4.30835 \\
IL-4 / IFN- $\gamma$ & 3.96000 & 2.05682 & .79571 & .25787 \\
\hline
\end{tabular}

Pada Tabel 1 terlihat bahwa pada penderita asma kadar IL-4 dan lgE total lebih besar dibandingkan kontrol. Tetapi kadar IFN- $\gamma$ total di dalam serum justru lebih kecil.

Dari tabel 2 terlihat bahwa FEV1 sangat berhubungan secara bermakna dengan kadar $\lg \mathrm{E}(\mathrm{p}=0.01)$, kadar IL-4 $(p=$ $0.008)$ dan rasio IL-4/ IFN- $\gamma(p=0.000)$, tetapi tidak bermakna dengan kadar IFN- $\gamma(p=0.805)$.
Pada Gambar 1 terlihat bahwa peningkatan kadar lgE total serum mempunyai korelasi yang bermakna $(p=0.01)$ dengan derajat obstruksi saluran nafas yang diukur dengan nilai FEV1. Makin berat derajat obstruksinya atau makin rendah nilai FEV1 maka kadar lgE total serum makin meningkat.

Tabel 2. Hasil analisis korelasi antar variabel

\begin{tabular}{|c|c|c|c|c|c|c|}
\hline & & FEV1 (\% Normal) & $\lg \mathrm{E}$ & IL-4 & IF-g & IL-4 / IF-g \\
\hline \multirow{3}{*}{ FEV1 (\% Normal) } & Pearson Correlation & 1.000 & $\left.-.310^{*}\right)$ & $-.319\left(^{* *}\right)$ & .030 & $\left.-.6511^{(*}\right)$ \\
\hline & Sig. (2-tailed) & & .010 & .008 & .805 & .000 \\
\hline & $\mathrm{n}$ & 68 & 68 & 68 & 68 & 68 \\
\hline \multirow{3}{*}{$\lg E$} & Pearson Correlation & $-.310\left(^{*}\right)$ & 1.000 & .088 & .049 & .087 \\
\hline & Sig. (2-tailed) & .010 & & .478 & .694 & .479 \\
\hline & $n$ & 68 & 68 & 68 & 68 & 68 \\
\hline \multirow{3}{*}{ IL-4 } & Pearson Correlation & $-.319\left({ }^{* *}\right)$ & .088 & 1.000 & $.746\left(^{* \star}\right)$ & $.452\left({ }^{* *}\right)$ \\
\hline & Sig. (2-tailed) & .008 & .478 & & .000 & .000 \\
\hline & $\mathrm{n}$ & 68 & 68 & 68 & 68 & 68 \\
\hline \multirow{3}{*}{ IF-g } & Pearson Correlation & .030 & .049 & $.746\left(^{* *}\right)$ & 1.000 & -.109 \\
\hline & Sig. (2-tailed) & .805 & .694 & .000 & & .374 \\
\hline & $\mathrm{n}$ & 68 & 68 & 68 & 68 & 68 \\
\hline \multirow{3}{*}{ IL-4 / IF-g } & Pearson Correlation & $-.651\left(^{* \star}\right)$ & .087 & $\left..452^{(* *}\right)$ & -.109 & 1.000 \\
\hline & Sig. (2-tailed) & .000 & .479 & .000 & .374 & \\
\hline & $\mathrm{n}$ & 68 & 68 & 68 & 68 & 68 \\
\hline
\end{tabular}

** Correlation is significant at the 0.01 level (2-tailed).

${ }^{*}$ Correlation is significant at the 0.05 level (2-tailed). 


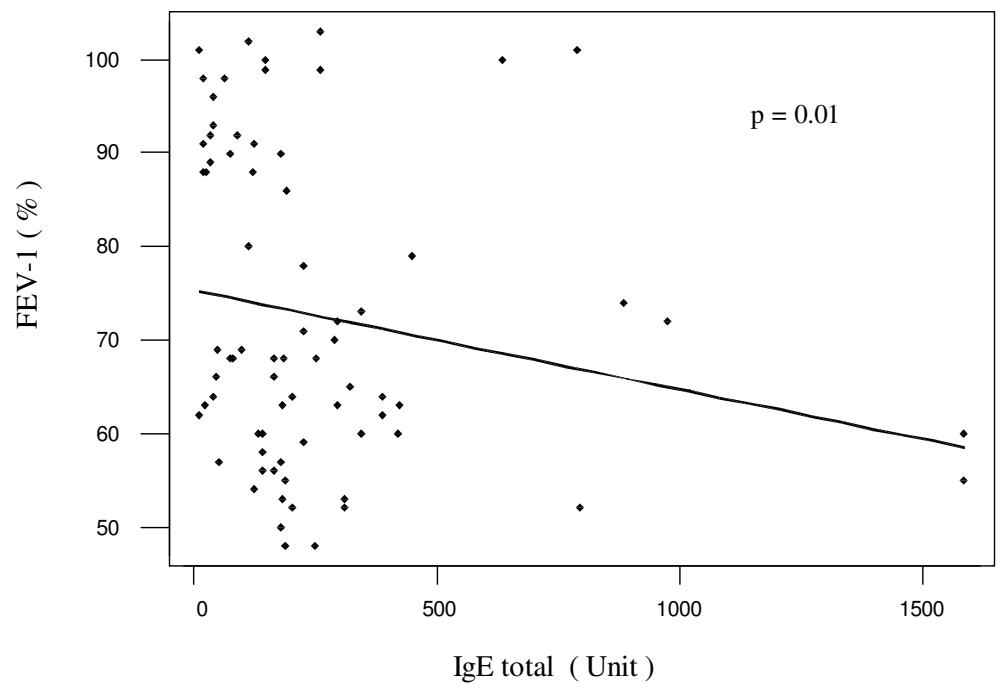

Gambar 1. Hubungan antara derajat obstruksi dengan IgE total (Regression Plot)

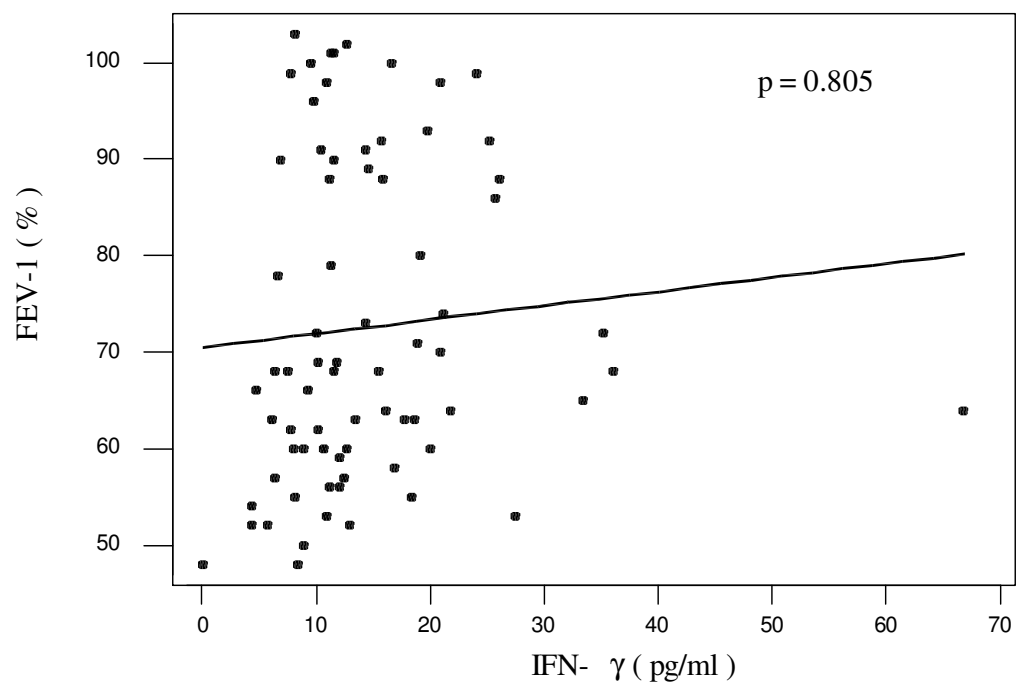

Gambar 2. Hubungan antara derajat obstruksi dengan kadar IFN- $\gamma$ (Regression Plot)
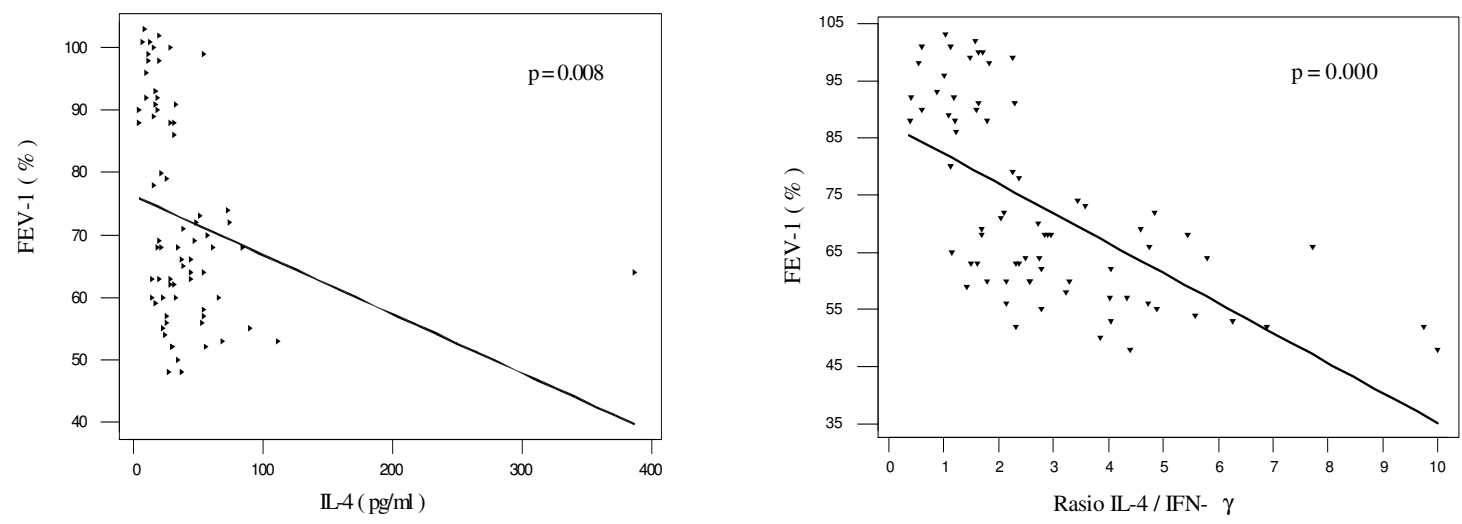

Gambar 3. Hubungan antara derajat obstruksi dengan kadar IL-4 dan Rasio IL4 / IFN- $\gamma$ (Regression Plot) 
Dari Gambar 2. walaupun hubungan antara kadar IFN- $\gamma$ total serum dengan derajat obstruksi saluran nafas tidak bermakna $(p=0.805)$ tetapi terlihat disini bahwa makin ringan derajat obstruksinya ( makin besar nilai FEV1) makin rendah kadar IFN- $\gamma$.

Dari Gambar 3 terlihat bahwa makin besar kadar IL-4 total serum dan rasio IL-4 / IFN- $\gamma$ makin besar pula derajat obstruksinya atau makin rendah nilai FEV1 masing-masing dengan $p=0.008$ dan $p=0.000$.

\section{DISKUSI}

Proses inflamasi saluran nafas yang mendasari penyakit asma diatur oleh jaringan kerja berbagai sitokin yang saling berinteraksi satu dengan lainnya. Peran fungsional yang pasti dari sitokin untuk tiap individu terhadap patogenesis asma masih terus diteliti.

Sel $\mathrm{T}$ penolong tipe 2( $\left.\mathrm{Th}_{2}\right)$ akhir-akhir ini dibuktikan mempunyai peran yang penting dalam proses inflamasi saluran nafas pada asma. Sitokin yang berperan penting dan berasal dari sel Th2 adalah IL-4, IL-13 dan IL-5. Pada penyakit asma peran sitokin saling terkait dan berinteraksi dengan sitokin lain disekitarnya. Ekspresi berlebihan dari sitokin inflamasi seperti TNF-a (Tumor Necrosis Factor - a) meningkatkan proses inflamasi yang terjadi dan berhubungan erat dengan derajat siviritas penyakit. Sebaliknya, apabila ekspresi sitokin immunoregulator menurun seperti IL-12, IL-18, dan IFN- $\gamma$ juga mampu meningkatkan proses inflamasi yang berasal dari sel $\mathrm{Th}_{2}$ $(2,4)$.

Dalam penelitian ini dibuktikan bahwa peningkatan kadar IgE serum mempunyai korelasi dengan makin rendahnya nilai FEV1 yang berarti bahwa peningkatan kadar IgE serum dapat menambah derajat obstruksi ke arah yang lebih berat. Sangat berbeda dengan penelitian yang dilakukan oleh Wilder dkk (1999) yang membuktikan bahwa peningkatan kadar lgE total atau lgE spesifik tidak secara langsung memicu terjadinya peningkatan responsivitas bronkus (5). Tampaknya penurunan FEV1 karena peningkatan kadar lgE total serum secara tidak langsung menggambarkan peran IL-4, mengingat sitokin IL-4 mempunyai peran langsung dalam IgE-switching (6).

Juga terdapat korelasi yang bermakna antara tingginya kadar IL-4 serum dengan menurunnya nilai FEV1, yang berarti bahwa makin tinggi kadar IL-4 di serum pada saat serangan akut asma maka makin berat derajat obstruksi yang terjadi. Temuan ini sesuai dengan temuan yang dijumpai oleh peneliti lain yaitu : bahwa IL-4 mempunyai implikasi dalam proses remodeling saluran nafas, menstimulasi produksi mukus dan fibroblas yang menyebabkan hiperresponsivitas bronkus yang meningkat. Juga telah dibuktikan bahwa polimorfisme dari gen IL-4 tertentu ekspresinya berhubungan dengan risiko asma berat (life threatening asthma) $(1,2)$. Pada hasil otopsi penderita yang meninggal karena status asmatikus dijumpai bahwa pola inflamasinya sesuai dengan pola paradigma $\mathrm{Th}_{2}$ yaitu ditemukan sitokin IL-4 yang berlebihan (3).

Dari penelitian ini walaupun tidak bermakna tampak bahwa makin besar kadar IFN- $\gamma$ maka makin ringan derajat obstruksi saluran nafas, karena nilai FEVnya juga makin besar. Tapi makin rendah kadar IFN- $\gamma$ makin berat derajat obstruksi saluran nafas yang terjadi. Fakta ini sesuai dengan pendapat para ahli yang membuktikan bahwa proses inflamasi saluran nafas di induksi oleh sitokin $\mathrm{Th}_{2}$ yang meningkat tapi juga oleh karena penurunan ekspresi dari sitokin $T_{1}$, termasuk di dalamnya $\operatorname{IFN}-\gamma(2,4)$. Sebaliknya pada kasus tertentu justru pada kasus serangan akut berat kadar IFN- $\gamma$ ditemukan berlebihan (7).

Untuk membuktikan dominasi peran IL-4 dalam serangan akut asma dan derajat obstruksinya, maka peneliti juga menemukan adanya korelasi yang bermakna antara rasio IL-4/ IFN- $\gamma$ dan derajat obstruksi saluran anfas yang terjadi. Terlihat bahwa makin tinggi rasio tersebut makin berat derajat obstruksi yang terjadi.Peneliti lain telah membuktikan bahwa peningkatan kadar IL-4, penurunan kadar IFN- $\gamma$ dan peningkatan rasio IL-4/ IFN- $\gamma$ menjadi pusat dan peran sentral dalam penyakit asma $(8,9,10,11)$. IFN- $\gamma$ dalam penelitian ini tampaknya tidak mempunyai korelasi yang bermakna dengan nilai FEV1 artinya derajat obstruksi serangan akut asma tidak atau kurang ditentukan oleh penurunan kadar IFN- $\gamma$. Tetapi peran penting yang menentukan derajat obstruksi saluran nafas pada serangan akut asma dalam penelitian ini adalah peningkatan IL-4 dan rasio IL-4/ IFN- $\gamma$.

\section{KESIMPULAN}

Dari penelitian ini IL-4 tampaknya merupakan sitokin yang dapat menentukan derajat obstruksi saluran nafas pada serangan akut asma. Menentukan rasio IL-4/ IFN- $\gamma$ lebih mempunyai nilai bermakna daripada hanya mengukur kadar IFN- $\gamma$ saja, apabila kita bermaksud untuk menentukan adanya korelasi dengan derajat obstruksi saluran nafas atau derajat berat serangan akut asma.

\section{DAFTAR KEPUSTAKAAN}

1. Leblond IT, Pugin J, Marquette $\mathrm{CH}$, et al. Balance between Proinflammatory Cytokines and Their Inhibitors in Bronchial Lavage from Patients with Status Asthmaticus. Am. J. Respir. Crit. Med. 1999; 159 (2): 487-494.

2. Kips JC. Cytokines in Asthma. Eur Respir J 2001; 18: 24S-33S.

3. American Thoracis Society. Proceedings of the ATS Workshop on Refractory Asthma. Current Understanding, recommendations, and Unanswered Questions. Am. J. Respir. Crit. Care Med. 2000; 162(6): 2341-2351.

4. Busse WW, Lemanske RF. Asthma. NEJM 2001; 344: 350-362.

5. Wilder JA, Collie DOS, Wilson BS, Bice DE, et al. Dissociation of Airway Hyperresponsible from Immunoglobulin $E$ and Airway Eosinophilia in a Marine-Model of Allergic Asthma. Am J. Respir. Cell Mol Biol. 1999; 20: 1326-1334.

6. Tobin MJ. Asthma, Airway Biology, and Nasal Disorders in AJRCCM. 2001. Year in Review. Am J Respir Crit Care Med. 2002;165: 598-618.

7. Corrigan KJ, Kay AB. CD4T Lymphocyte Activation in Acute Severe Asthma. Int Arch Allergy Appl Immunol 1991; 94 (1 - 4): 270-1. 
8. Foster PS, Hogan SP, Young IG, Mathaei KI. The Modulation of Allergic Airways Disease by Interleukin - 4 and - 5: Studies Using

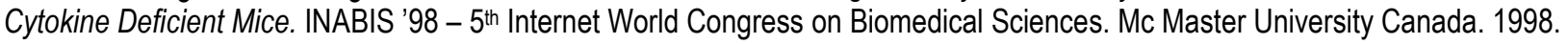

9. Foster PS, Yang M, Herbert C, Kumar RK. $\mathrm{CD}_{4}{ }^{+} T$ - Lymphocyte Regulate Airway Remodelling and Hyper-Reactivity in a Mouse Model of Chronic Asthma. Lab Invest; 2002; 82: 455-462.

10. Webb DC, Mekenzie ANJ, Kostinen AML, et al. Integrated Signalis Between IL-13, IL-4, and IL-5 Regulate Airways Hyperreactivity. J Immunol 2000; 165: 108 - 113.

11. Shahid SK, Kharitonov SA, Wilson NM, Bush A, Barnes PJ. Increased Interleukin - 4 and Decreased Interferon - $\gamma$ in Exhaled Breath Condensate of Children with Asthma. Am J Respir Crit Care Med. 2002; 165: 1290-1293. 